\title{
Importance of fast ice and glacier fronts for female polar bears and their cubs during spring in Svalbard, Norway
}

\author{
Carla Freitas ${ }^{1,2, *}$, Kit M. Kovacs ${ }^{1}$, Magnus Andersen ${ }^{1}$, Jon Aars ${ }^{1}$, Stein Sandven ${ }^{3}$, \\ Mette Skern-Mauritzen ${ }^{1,4}$, Olga Pavlova ${ }^{1}$, Christian Lydersen ${ }^{1}$ \\ ${ }^{1}$ Norwegian Polar Institute, Fram Centre, 9296 Tromsø, Norway \\ ${ }^{2}$ CIIMAR-Madeira, Centre of Marine and Environmental Research, Rua Pedra d'Eira, 9200-031 Caniçal, Madeira, Portugal \\ ${ }^{3}$ Nansen Environmental and Remote Sensing Centre, Thormøhlensgata 47, 5006 Bergen, Norway \\ ${ }^{4}$ Marine Mammal Research Group, Institute of Marine Research, PO Box 1870 Nordnes, 5817 Bergen, Norway
}

\begin{abstract}
Arctic sea ice is declining rapidly, making it vital to understand the importance of different types of sea ice for ice-dependent species such as polar bears Ursus maritimus. In this study we used GPS telemetry (25 polar bear tracks obtained in Svalbard, Norway, during spring) and high-resolution synthetic aperture radar (SAR) sea-ice data to investigate fine-scale space use by female polar bears. Space use patterns differed according to reproductive state; females with cubs of the year (COYs) had smaller home ranges and used fast-ice areas more frequently than lone females. First-passage time (FPT) analysis revealed that females with COYs displayed significantly longer FPTs near $(<10 \mathrm{~km})$ glacier fronts than in other fast-ice areas; lone females also increased their FPTs in such areas, but they also frequently used drifting pack ice. These results clearly demonstrate the importance of fast-ice areas, in particular close to glacier fronts, especially for females with COYs. Access to abundant and predictable prey (ringed seal pups), energy conservation and reluctance to cross large open water areas are possible reasons for the observed patterns. However, glacier fronts are retracting in Svalbard, and declines in land-fast ice have been notable over the past decade. The eventual disappearance of these important habitats might become critical for the survival of polar bear cubs in Svalbard and other regions with similar habitat characteristics. Given the relatively small size of many fast-ice areas in Svalbard, the results observed in this study would not have been revealed using less accurate location data or lowerresolution sea-ice data.
\end{abstract}

KEY WORDS: Ursus maritimus · Arctic sea ice · Ringed seals $\cdot$ Pusa hispida $\cdot$ First-passage time · Cox proportional hazard models $\cdot$ GPS telemetry $\cdot$ Home range

\section{INTRODUCTION}

Global warming is having a dramatic effect on sea ice in the Arctic (Vinnikov et al. 1999, IPCC 2007). Numerous studies have indicated that both multiyear ice and annual sea ice cover is shrinking in extent, and sea ice thickness is decreasing (Comiso 2002, Lindsay \& Zhang 2005, Stroeve et al. 2005, 2007,
Maslanik et al. 2007, Nghiem et al. 2007, Comiso et al. 2008, Kwok et al. 2009). Sea ice conditions are expected to continue to decline in the coming decades, perhaps at an accelerated rate (Holland et al. 2006, Serreze et al. 2007, Boe et al. 2009). These observations and predictions have raised concern about the conservation of many ice-dependent Arctic marine mammals, among them the polar bear Ursus 
maritimus (Stirling \& Derocher 1993, Derocher et al. 2004, Aars et al. 2006, Stirling \& Parkinson 2006, Wiig et al. 2008, Amstrup et al. 2010). Polar bears depend on sea ice as a platform for hunting their favoured prey, ice-associated seals (Stirling \& Archibald 1977, Smith 1980, Derocher et al. 2002, Thiemann et al. 2008). Sea ice is also used as a platform for other polar bear activities including mating and travelling to and from maternity denning areas, which are located on land in most Arctic areas (see Wiig et al. 2008). Evidence of declines in polar bear body condition, reproductive success, survival and abundance have been documented in the Canadian Arctic and the Beaufort Sea off Alaska; these changes are thought to be the result of nutritional limitations imposed by declining sea ice (Stirling et al. 1999, Regehr et al. 2007, 2010, Rode et al. 2010). Predictions of future polar bear abundance (Hunter et al. 2010, Molnar et al. 2010) and habitat distribution (Durner et al. 2009, Amstrup et al. 2010) based on predicted sea-ice trends are potential tools for population management (e.g. setting harvest quotas or making conservation status decisions). Extensive knowledge on the relationship between sea-ice conditions and polar bear behaviour is essential to refine such predictions and to identify critical habitat used by bears in different reproductive states.

The polar bear's annual cycle is characterised by a spring/summer season with very active foraging, followed by a less active period in autumn and winter (Messier et al. 1992, Amstrup et al. 2000, Ferguson et al. 2001). Mating occurs during spring (Lønø 1970, Rosing-Asvid et al. 2002), and pregnant females give birth in maternity dens the following winter (Messier et al. 1994, Van de Velde et al. 2003). After 4 to 8 mo without food while inside the den (see Watts \& Hansen 1987, Atkinson \& Ramsay 1995), polar bear mothers head for the sea ice to hunt seals shortly after they emerge from the den. Non-pregnant bears do not den for extended periods, although they often use shelters in the snow for shorter periods (often 1.5 to $2 \mathrm{mo}$ ) during winter, possibly to conserve energy and get protection from harsh weather conditions (Messier et al. 1994, Ferguson et al. 2000b). Depending on the geographical area, polar bears either remain on the sea ice year round or move to terrestrial areas for part of the year (Stirling et al. 1977, Ferguson et al. 1999, Mauritzen et al. 2001).

Previous studies have shown that polar bear distribution is significantly affected by sea ice concentration and type (Stirling et al. 1993, Arthur et al. 1996, Ferguson et al. 2000a, 2001, Mauritzen et al.
2003, Durner et al. 2009). Polar bears select sea-ice areas with concentrations ranging from 25 to $100 \%$, depending on the season and region (Stirling et al. 1993, Arthur et al. 1996, Ferguson et al. 2000a, 2001, Mauritzen et al. 2003, Durner et al. 2009). In the Canadian Arctic, females with cubs of the year (COYs) select land-fast ice (i.e. stationary sea ice attached to land) with pressure ridges during the spring, while lone adult females and males show strong preferences for ice-edge areas (Stirling et al. 1993). Females with COYs were thought to select fast-ice habitats in order to feed on ringed seal pups and to avoid adult males that are rare in this habitat; male bears sometimes prey on cubs (Stirling et al. 1993). In the Norwegian Arctic (Svalbard and the Barents Sea), female polar bears with COYs also show a year-round tendency to be located on more solid ice than lone adult females (Mauritzen et al. 2003).

In the present study, we combined high resolution GPS movement data with synthetic aperture radar (SAR) sea-ice data to investigate fine-scale space use by female polar bears. The use of such high-resolution data is required in coastal areas where habitat diversity is large and varies at small spatial scales. We investigated space use in terms of home range size and frequency of use of different sea-ice types; additionally, we used first-passage times (FPTs; Fauchald \& Tveraa 2003) to investigate space use intensity. We hypothesised that, in addition to sea-ice characteristics and reproductive status, space use patterns may also be affected by other landscape features. We therefore investigated the possible effect of such variables using Cox proportional hazard modelling.

\section{MATERIALS AND METHODS}

\section{Study area and period}

We carried out this study in Storfjorden (approximately $76-79^{\circ} \mathrm{N}, 15-25^{\circ} \mathrm{E}$ ), in the Svalbard Archipelago, Norway. Storfjorden is situated between Spitsbergen, Barentsøya and Edgeøya (Fig. 1). The fjord is approximately $250 \mathrm{~km}$ long and $150 \mathrm{~km}$ wide at the broadest section; it is seasonally ice covered, normally from late November to mid-May (Haarpaintner et al. 2001, Skogseth et al. 2004). Fast ice is usually formed in the northern part of the fjord and along the coasts, while a mobile field of pack ice covers the rest of the fjord (Haarpaintner et al. 2001, Smedrud et al. 2006) except for a few polynyas (open 


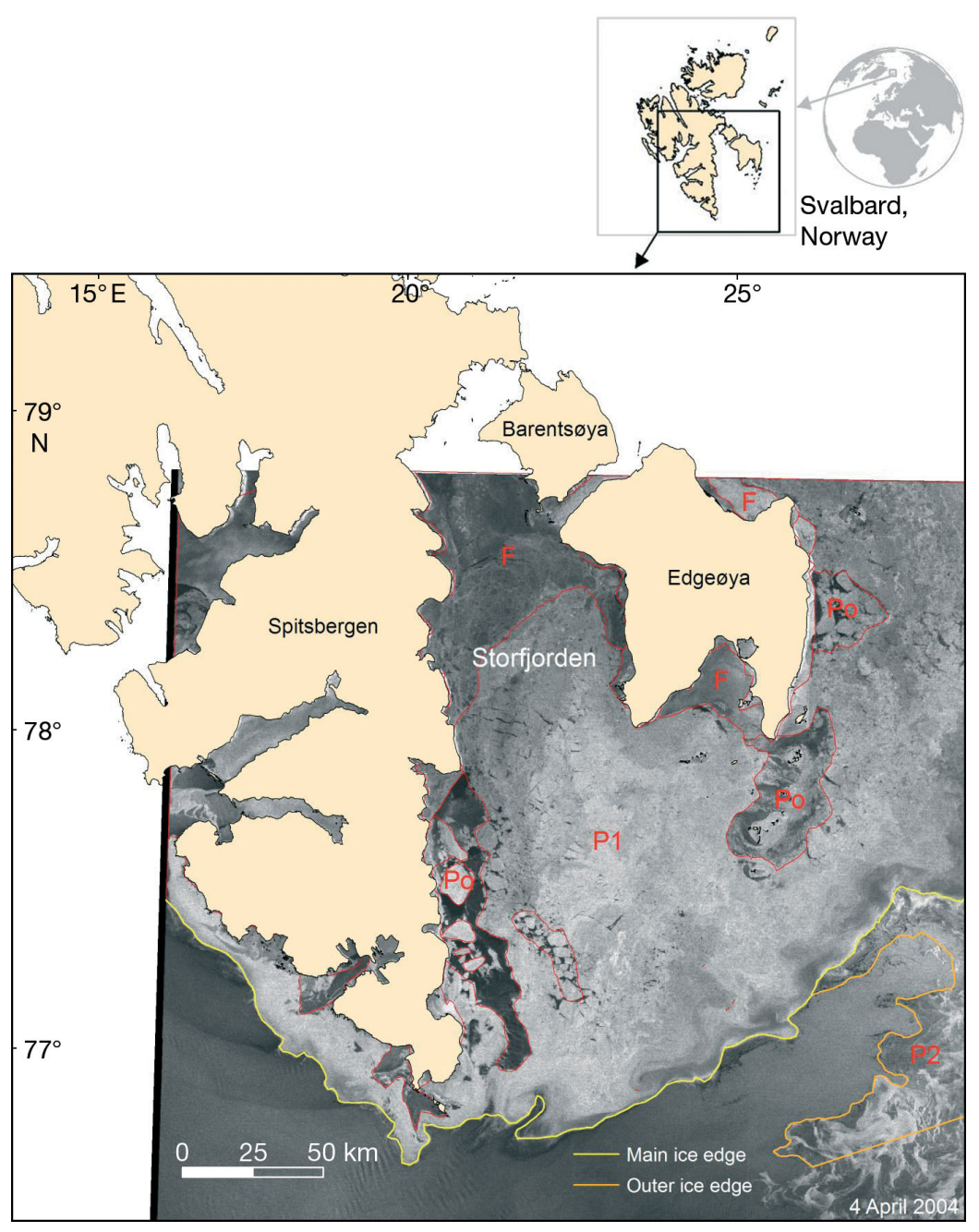

Fig. 1. Geographical limits of the study and an example of a synthetic aperture radar (SAR) image we used in the study with its corresponding sea ice classification (F: fast ice; P1: pack ice between 50 and $100 \%$ concentration; P2: pack ice between 10 and $50 \%$ concentration; Po: polynya). The main ice edge (at about $50 \%$ concentration) and outer ice edge (at about $10 \%$ sea ice concentration) are also highlighted on the image

water areas in ice-covered seas) that appear regularly in the fjord during periods with north-easterly winds (Haarpaintner et al. 2001, Skogseth et al. 2004, Smedrud et al. 2006). Polynyas are often especially productive and hence attractive to marine mammals (Stirling 1997).

Since the satellite radar images used for sea ice analysis in this study had to be ordered in advance of the fieldwork, the study period had to be defined a priori. We chose April as the study period since this is the time of the year when female polar bears with COYs emerge from their maternity dens after 4 or more months of fasting (Lønø 1970, Wiig 1998). April is also a peak period for polar bear mating
(Lønø 1970, Rosing-Asvid et al. 2002, Derocher et al. 2010) in addition to being the peak birthing period for ringed seals in Svalbard (Lydersen 1998).

\section{Polar bear data}

We captured polar bears in Storfjorden either on shore (August 2002) or on the shore-fast sea ice (April 2003 and April 2004). We immobilised individual animals from a helicopter using a remotely injected dose of Zoletil ${ }^{\circledR}$ following Stirling et al. (1989). We deployed GPS collars (model TGW3680, GEN 3, Telonics) on adult female bears. Capture and handling methods were approved by the Norwegian Animal Research Authority and the Governor of Svalbard.

We programmed the GPS transmitters to collect 6 positions daily at $4 \mathrm{~h}$ intervals, resulting in an expected tag lifetime of 15 mo. Data were transmitted via the Argos System (see Andersen et al. 2008). We processed the data using Telonics ADC-T03 software (version 2.0). We used only locations with a fix status 'Good' (quality indicator) in our analyses. We used all tracks that were obtained from the defined study area (see above) during April 2003 and April 2004. A total of 15 different adult female polar bears were tracked within this area in April 2003 and 10 in April 2004. Nine of the 10 bears tracked in 2004 were also tracked in 2003 (Table 1). This study is thus based on 25 different tracks derived from 16 individuals (Table 1).

We classified female polar bears into 3 reproductive groups: with COYs (female with 1 or more COYs, approximately 4 mo old), with yearlings (female with 1 or more cubs born the previous year, approximately $16 \mathrm{mo}$ old) and lone adult (female with no dependent offspring). We determined reproductive status from direct observations during capture or from telemetry data (denning data) for the year after capture. Adult polar bear females normally breed every second or third year (Ramsay \& Stirling 1988, Wiig 1998) and use dens for extended periods only when pregnant (Ramsay \& Stirling 1988, Amstrup \& Gardner 1994, 
Table 1. Ursus maritimus. Summary of 25 tracking records of 16 individual polar bears obtained in Storfjorden, Svalbard, in April 2003 and April 2004. Abbreviations for reproductive status: COYs: female with cubs of the year; Yrlg: female with yearlings; Lone: lone adult female

\begin{tabular}{|c|c|c|c|c|c|c|c|c|}
\hline $\begin{array}{l}\text { Track } \\
\mathrm{N}\end{array}$ & Track ID & $\begin{array}{l}\text { Individual } \\
\text { ID }\end{array}$ & $\begin{array}{l}\text { Capture } \\
\text { date }\end{array}$ & $\begin{array}{l}\text { Month } \\
\text { tracked }\end{array}$ & $\begin{array}{l}\mathrm{N} \text { days } \\
\text { tracked }\end{array}$ & $\begin{array}{l}\text { N GPS } \\
\text { locations }\end{array}$ & $\begin{array}{l}\text { Reproductive } \\
\text { status }\end{array}$ & $\begin{array}{l}\text { Reproductive status } \\
\text { determined from }\end{array}$ \\
\hline 1 & 2003_2166 & Ind_01 & 19 Apr 2003 & Apr 2003 & 10 & 48 & COYs & Capture \\
\hline 2 & 2003_2170 & Ind_02 & 19 Apr 2003 & Apr 2003 & 9 & 36 & Lone & Capture \\
\hline 3 & 2003_2172 & Ind_03 & 5 Apr 2003 & Apr 2003 & 25 & 115 & COYs & Capture \\
\hline 4 & 2003_2174 & Ind_04 & 19 Apr 2003 & Apr 2003 & 10 & 56 & Yrlg & Capture \\
\hline 5 & 2003_2175 & Ind_05 & 16 Apr 2003 & Apr 2003 & 13 & 49 & Lone & Capture \\
\hline 6 & 2003_2178 & Ind_06 & 19 Apr 2003 & Apr 2003 & 11 & 60 & COYs & Capture \\
\hline 7 & 2003_2182 & Ind_07 & $\begin{array}{l}20 \text { Aug 2002/ } \\
21 \text { Apr } 2003\end{array}$ & Apr 2003 & $9+9^{a}$ & $41+33$ & COYs & Capture \\
\hline 8 & 2003_2185 & Ind_08 & 15 Apr 2003 & Apr 2003 & 15 & 74 & Lone & Capture \\
\hline 9 & 2003_9678 & Ind_09 & 21 Aug 2002 & Apr 2003 & 28 & 106 & COYs & Telemetry (denning) \\
\hline 10 & 2003_9679 & Ind_10 & 19 Aug 2002 & Apr 2003 & 29 & 126 & Lone & Telemetry (not denning) \\
\hline 11 & 2003_9684 & Ind_11 & 10 Apr 2003 & Apr 2003 & 19 & 82 & Yrlg & Capture \\
\hline 12 & 2003_9690 & Ind_12 & 21 Aug 2002 & Apr 2003 & 27 & 118 & COYs & Telemetry (denning) \\
\hline 13 & 2003_9692 & Ind_13 & 21 Aug 2002 & Apr 2003 & 29 & 84 & COYs & Telemetry (denning) \\
\hline 14 & 2003_9695 & Ind_14 & 19 Aug 2002 & Apr 2003 & 29 & 94 & COYs & Telemetry (denning) \\
\hline 15 & 2003_9696 & Ind_15 & 15 Apr 2003 & Apr 2003 & 15 & 74 & Yrlg & Capture \\
\hline 16 & 2004_2165 & Ind_16 & 15 Apr 2004 & Apr 2004 & 15 & 61 & Lone & Capture \\
\hline 17 & 2004_2170 & Ind_02 & 19 Apr 2003 & Apr 2004 & 29 & 124 & COYs & Telemetry (denning) \\
\hline 18 & 2004_2172 & Ind_03 & $\begin{array}{l}5 \text { Apr 2003/ } \\
12 \text { Apr 2004 }\end{array}$ & Apr 2004 & 29 & 123 & Lone & Capture \\
\hline 19 & 2004_2174 & Ind_04 & 19 Apr 2003 & Apr 2004 & 20 & 51 & Lone $^{b}$ & Telemetry (not denning) \\
\hline 20 & 2004_2175 & Ind_05 & 16 Apr 2003 & Apr 2004 & 29 & 114 & COYs & Telemetry (denning) \\
\hline 21 & 2004_2178 & Ind_06 & $\begin{array}{l}19 \text { Apr 2003/ } \\
21 \text { Apr 2004 }\end{array}$ & Apr 2004 & 10 & 25 & Lone & Capture \\
\hline 22 & 2004_2185 & Ind_08 & 15 Apr 2003 & Apr 2004 & 22 & 52 & COYs & Telemetry (denning) \\
\hline 23 & 2004_9684 & Ind_11 & 10 Apr 2003 & Apr 2004 & 29 & 119 & Lone $^{b}$ & Telemetry (not denning) \\
\hline 24 & 2004_9692 & Ind_13 & 21 Aug 2002 & Apr 2004 & 18 & 27 & COYs & Telemetry (denning) \\
\hline 25 & 2004_9696 & Ind_15 & 15 Apr 2003 & Apr 2004 & 27 & 58 & Lone $^{b}$ & Telemetry (not denning) \\
\hline
\end{tabular}

Messier et al. 1994, Ferguson et al. 2000b, Van de Velde et al. 2003). While inside dens, few or no GPS positions are received by the Argos satellites because signals are obstructed by the snow cover. We concluded that females had entered a den if they displayed significant gaps in data transmission during 3 or more months between December and March, and transmitted location data from the same area both before and after the gap. If females did not enter a den, we assumed that they followed the 3 yr cycle: with COYs, with yearlings and then as a lone adult. Female polar bears normally nurse their cubs for 2.5 yr with separation and subsequent mating occurring during the third spring following a birthing event (Ramsay \& Stirling 1988, Wiig 1998). Thus, 3 females with yearlings captured in 2003 were categorised as lone adult females in 2004 (see Table 1), although they might have been accompanied by 2 yr old cubs during April.

\section{Sea ice data}

We used SAR images from the ENVISAT satellite, with a resolution of $300 \mathrm{~m}$, from southern Svalbard from April 2003 ( $n=13$ ) and April 2004 ( $\mathrm{n}=13$; see example in Fig. 1). SAR images were not available regularly at this time, so we had to order them in advance from the European Space Agency (ESA) specifically to support these field investigations. Not all of the ordered images were delivered, resulting in some temporal gaps in our data coverage during the study period (number of days missing between images ranged from 0 to 7 ; average $1.4 \mathrm{~d}$ ).

We identified the most probable ice types, based on the backscatter coefficient values from the images (image grey tones). We manually set polygon lines on the images, such that each polygon contained an area with a large-scale homogeneous backscatter coefficient, which corresponded to a given type of ice 
or open water, using the following classification: (1) fast ice (sea ice surface that remains stationary, attached to the coast or grounded); (2) pack ice (sea ice in motion covering 10 to $100 \%$ of the water surface); (3) polynya (area of open water or very thin ice in a generally ice-covered area); and (4) open water (Fig. 1). In addition, we defined 2 ice-edge boundary lines on the images, the main ice edge (defined by $50 \%$ ice concentration) and an outer ice edge marking the border between scattered ice and open ocean (defined by $10 \%$ ice concentration). This enabled us to subdivide pack-ice areas into 50 to $100 \%$ sea ice concentration and 10 to $50 \%$ sea ice concentration (Fig. 1).

\section{Data analysis}

We analysed the data using $\mathrm{R}$ (version 2.11.0, $\mathrm{R}$ Development Core Team 2010) and ArcGIS (version 9, ESRI) software. We estimated home ranges as minimum convex polygons (Mohr 1947), using the R package adehabitat (Calenge 2006). These polygons provide the limits of the overall area used by each individual. Given that track periods ranged from 9 to $29 \mathrm{~d}$ (Table 1) and that we could not calculate home ranges on a daily basis due to the lack of a minimum number of locations (5) on some days, we calculated home ranges for a moving window of $9 \mathrm{~d}$, at $1 \mathrm{~d}$ steps, meaning that an $11 \mathrm{~d}$ long track, for example, provided three $9 \mathrm{~d}$ home ranges. We then averaged these home ranges for each track and investigated home-range size versus reproductive status, using mixed-effects analysis of variance (ANOVA). In order to take into account that some individuals were used in both years (many of them having changed reproductive status from one year to the other; see Table 1), we used individual identification as random factor in the models. Because home ranges were not linearly distributed, we used log transformation to achieve linearity and homogeneity of variances prior to the application of the ANOVA.

We calculated the distance to shore for each GPS location, using ArcGIS and newly updated coastline data provided by the Norwegian Polar Institute mapping division. We also calculated the distance to the nearest coastal glacier front for the same GPS locations. We averaged these distances for each track, excluding on-shore locations when calculating these averages. Similar to our home range analyses, we then tested the impact of reproductive status using mixed-effects ANOVA, with individual identity as a random factor. Again, we log-transformed distances to achieve linearity and homogeneity of variances. In order to investigate possible sampling bias, or different habitat use patterns, at the time of capture we tested whether distance to shore and distance to glaciers at the time of capture in April were significantly different among females of different reproductive status, using 1-way ANOVA. To explore finescale habitat use, we extracted sea-ice type occupied for each GPS location from the SAR images for the corresponding day, using ArcGIS. Some areas of Storfjorden were consistently covered by the same sea-ice type over a period of several days. Consequently, we interpolated sea-ice type for locations with no SAR image for a particular day if the sea-ice type was consistent in the previous and next images available. In total, we classified sea-ice type for 489 locations from days with SAR images (306 on fast ice, 183 on pack ice) and 432 locations from days in between SAR images (272 on fast ice, 160 on pack ice). We used Kruskal-Wallis tests to investigate whether the frequency of use of the different types of sea ice was different for bears based on their reproductive status.

We used FPTs to investigate space-use intensity. FPT is defined as the time required for an animal to cross a circle of a given radius (from the time it entered the circle to the time it first left the circle) and is therefore a scale-dependent measure of search effort (Fauchald \& Tveraa 2003). Variance in FPT (at different radii) can be used to identify the spatial scale of area restricted search (ARS; Fauchald \& Tveraa 2003, 2006). The method requires that location data are spaced at equal spatial intervals along the track line (Fauchald \& Tveraa 2003, 2006). Thus, we generated new positions along the track line between actual GPS fixes, at $5 \mathrm{~km}$ intervals. We calculated FPTs based on these new positions, for circles with radii ranging from $500 \mathrm{~m}$ to $30 \mathrm{~km}$, at $500 \mathrm{~m}$ intervals. We identified the spatial scales of ARS using plots of variance in log-transformed FPT versus radii, combined with a plotting of the tracks on a map. Some bears did not show a peak in variance but used a restricted area (with radii ranging from 5 to $18 \mathrm{~km}$ ) during the whole tracking period (Fig. 2, Table 2). Given the variability in ARS radii among tracks (see Table 2), we compared FPTs at 3 different spatial scales: 2, 5 and $10 \mathrm{~km}$. Greater radii would exclude several individuals from the analyses. After investigating the ARS spatial scales (from the regularly-spaced tracks), we calculated FPTs for radii of 2, 5 and $10 \mathrm{~km}$ using the original GPS locations. This ensured that we used FPTs and environmental variables in the FPT modelling (see below) obtained at 


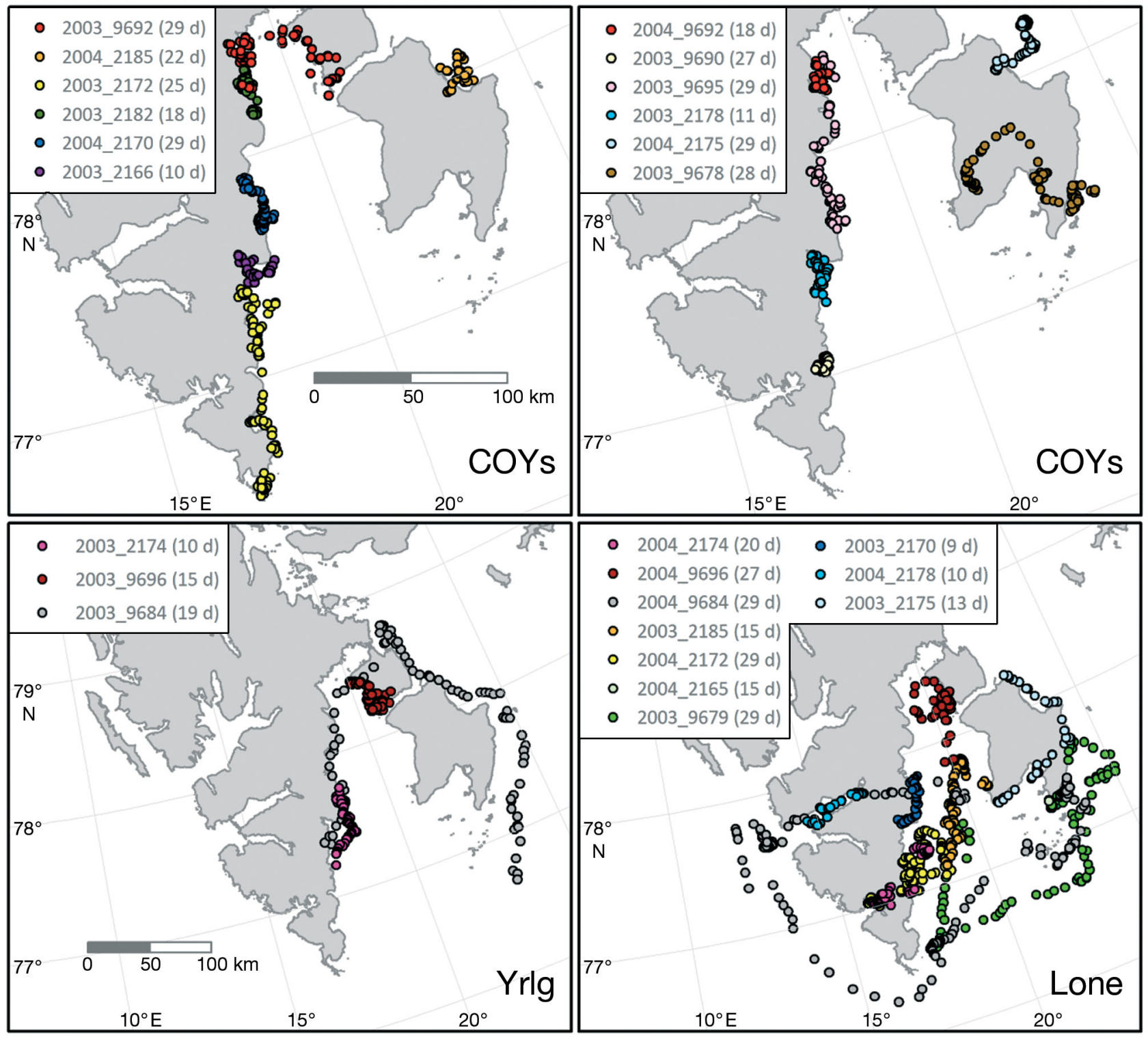

Fig. 2. Ursus maritimus. Polar bear GPS locations obtained in the Storfjorden area (Svalbard) in April 2003 and April 2004 . The upper panels show locations from females with cubs of the year (COYs), while the bottom left and right panels are for females with yearlings (Yrlg) and lone adult females (Lone), respectively. Two panels were used for females with COYs to increase readability. Positions for each individual are displayed with the same colour. Track ID and number of tracking days are displayed in the keys

the exact GPS locations of the bears and not at interpolated locations which in principle the bears might not have used. We then compared FPTs using random-effects Cox proportional hazard models (Freitas et al. 2008). These analyses model the probability of leaving an area (of 2,5 and $10 \mathrm{~km}$ radius) as a function of various explanatory variables that could affect polar bear FPTs including reproductive status, seaice type, distance to shore and distance to the nearest coastal glacier front. We used distance to the nearest glacier front as an explanatory variable since fast-ice areas close to glacier fronts are known to be prime breeding habitat for ringed seals in Svalbard (Lydersen \& Ryg 1991, Smith \& Lydersen 1991, Krafft et al. 2007). Because distance to shore and distance to glacier fronts were highly correlated (Pearson's correlation, $r=0.84$ ) these 2 variables were not used simultaneously in our models to avoid collinearity problems. Instead we fitted 2 models sequentially, each containing 1 of the variables, and compared 


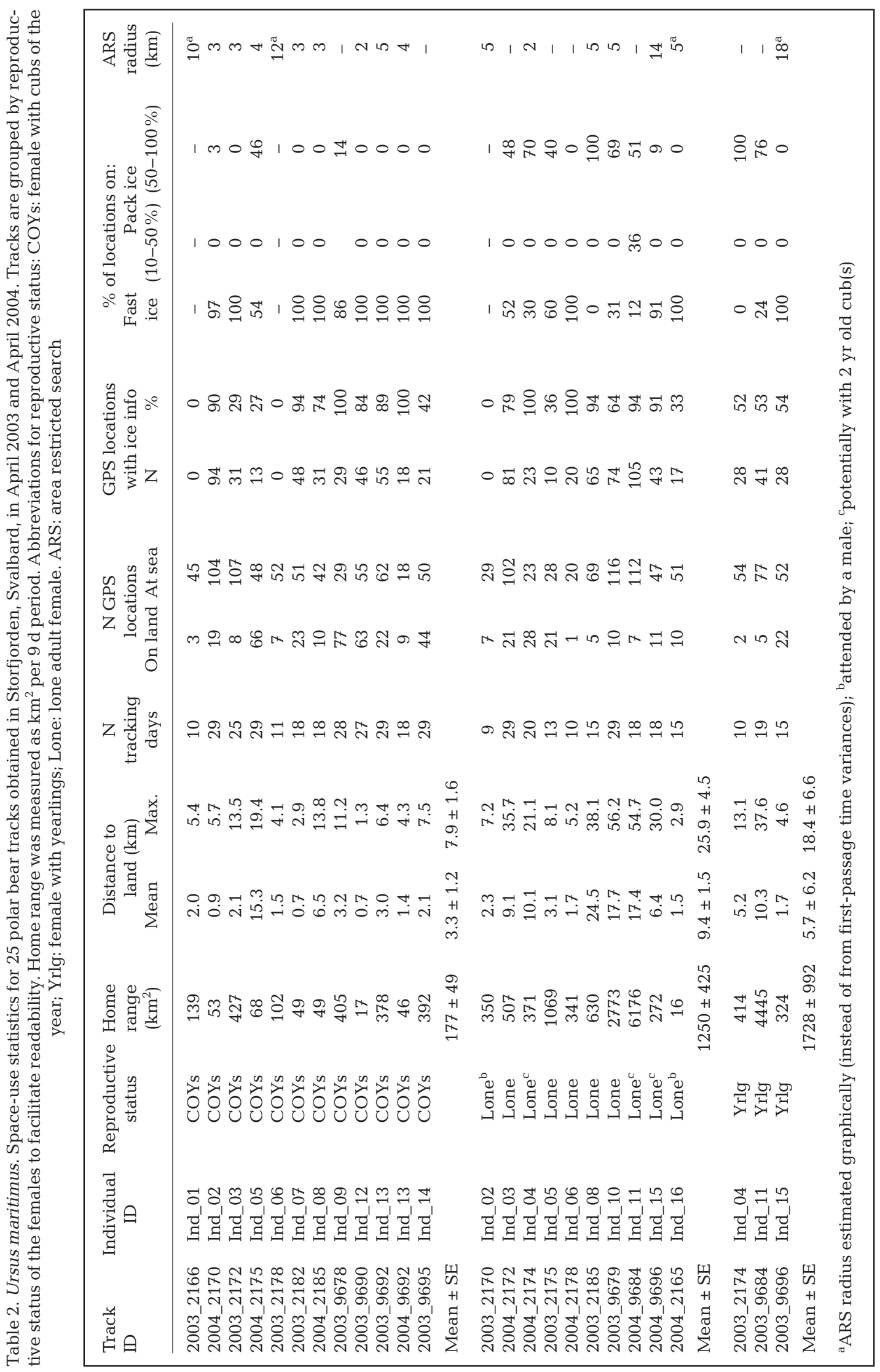


their Akaike information criterion values, corrected to the effective sample size $\left(\mathrm{AIC}_{\mathrm{C}}\right.$, Burnham \& Anderson 2002). We then removed from the analysis the variable explaining the least deviance (the one having the highest $\mathrm{AIC}_{\mathrm{ci}}$ Table 3) Since fast-ice areas are generally located closer to shore (and to glaciers) compared to most pack-ice areas, this could also lead to a confounding effect between these variables. Consequently, in addition to the main model, including all ice types, we investigated FPTs more closely for fast-ice and pack-ice areas separately. We performed model selection using forward selection based on the $\mathrm{AIC}_{\mathrm{c}}$ (Table 3). We used individual identity as a random-effects variable in all models in order to take individual variation into account and to minimise pseudo-replication issues.

\section{RESULTS}

The duration of the April polar bear tracks ranged from 9 to 29 consecutive days (Table 1, Fig. 2). Most of the 9 bears that were tracked in consecutive years showed fidelity to the same geographic area within
Storfjorden (Fig. 3). Home range size differed significantly among females of various reproductive status, and these differences were not significantly affected by the random variation between individuals (mixedeffects ANOVA, differences between reproductive status: $F_{2,7}=5.67, \mathrm{p}=0.034$; random variation between individuals: $F_{2,13}=2.48, \mathrm{p}=0.122$ ). Females with COYs displayed significantly smaller $9 \mathrm{~d}$ home ranges (mean $=177.0 \mathrm{~km}^{2}, 95 \% \mathrm{CI}=81.9$ to $272.1 \mathrm{~km}^{2}, \mathrm{n}=12$ ) compared with lone adult females (mean $=1250.5 \mathrm{~km}^{2}, 95 \% \mathrm{CI}=73.7$ to $2427.2 \mathrm{~km}^{2}, \mathrm{n}=$ $10)$, while females with yearlings $(n=3)$ were intermediate in their behaviour compared to the other 2 groups and not statistically different from either at $\mathrm{p}<0.05$ (Tukey post hoc tests).

Females with COYs generally remained closer to shore $($ mean $=3.3 \mathrm{~km}, 95 \% \mathrm{CI}=1.0$ to $5.6 \mathrm{~km}$, maximum $19.4 \mathrm{~km}, \mathrm{n}=12$ ) than lone adult females (mean = $9.4 \mathrm{~km}, 95 \% \mathrm{CI}=4.4$ to $14.4 \mathrm{~km}$, maximum $56.2 \mathrm{~km}, \mathrm{n}$ =10; Fig. 2). However, differences between reproductive status were not significantly different when taking individual variability into account (mixedeffects ANOVA, differences between reproductive status: $F_{2,7}=1.50, \mathrm{p}=0.287$; random variation

Table 3. Ursus maritimus. Ranking of alternative models used to explain the probabilities of polar bears leaving a given area, based on the Akaike information criterion corrected for the actual sample size $\left(\mathrm{AIC}_{\mathrm{c}}\right)_{\text {; }}$ the most parsimonious model is presented in bold. $\mathrm{AIC}_{\mathrm{c}}$ differences $\Delta_{i}$ and Akaike weights $w_{i}$ (which show the weight of evidence of each model) are also given. $\mathrm{AIC}_{\mathrm{C}}$ values were used both (a) to select between pairs of highly correlated variables and (b) for model selection. AIC ${ }_{\mathrm{c}} \Delta_{i}$ and $w_{i}$ are given for models fitted to first-passage times (FPTs) at 2, 5 and $10 \mathrm{~km}$ radii. Glac: distance to the nearest glacier front; Land: distance to shore; Ice: sea-ice concentration; Repr: reproductive status

\begin{tabular}{|c|c|c|c|c|c|c|c|c|c|c|}
\hline & \multirow{2}{*}{ Model } & \multicolumn{3}{|c|}{$2 \mathrm{~km}$} & \multicolumn{3}{|c|}{$-5 \mathrm{~km}-$} & \multicolumn{3}{|c|}{$-10 \mathrm{~km}$} \\
\hline & & $\mathrm{AIC}_{\mathrm{c}}$ & $\Delta_{i}$ & $w_{i}$ & $\mathrm{AIC}_{\mathrm{c}}$ & $\Delta_{i}$ & $w_{i}$ & $\mathrm{AIC}_{\mathrm{c}}$ & $\Delta_{i}$ & $w_{i}$ \\
\hline \multicolumn{11}{|c|}{ (a) Selection between correlated variables } \\
\hline \multirow[t]{2}{*}{ Main model } & Glac & 10336.9 & 0.0 & 1.00 & 13178.2 & 0.0 & 1.00 & 15852.6 & 0.0 & 1.00 \\
\hline & Land & 13047.2 & 2710.3 & 0.00 & 17568.8 & 4390.7 & 0.00 & 21073.5 & 5220.9 & 0.00 \\
\hline \multirow[t]{2}{*}{ Fast ice } & Glac & 5411.0 & 0.0 & 0.97 & 4072.7 & 0.0 & 1.00 & 2706.2 & 0.0 & 1.00 \\
\hline & Land & 5418.0 & 7.0 & 0.03 & 4094.6 & 21.9 & 0.00 & 2717.2 & 10.9 & 0.00 \\
\hline \multirow[t]{2}{*}{ Pack ice } & Land & 3129.5 & 0.0 & 0.98 & 2929.6 & 0.0 & 1.00 & 2740.7 & 0.0 & 1.00 \\
\hline & Glac & 3137.1 & 7.6 & 0.02 & 2954.8 & 25.3 & 0.00 & 2765.6 & 24.9 & 0.00 \\
\hline \multicolumn{11}{|c|}{ (b) Model selection } \\
\hline \multirow{6}{*}{ Main model } & Ice + Repr + Glac & 9563.4 & 0.0 & 1.00 & 7946.3 & 0.0 & 1.00 & 6107.9 & 0.0 & 1.00 \\
\hline & Ice + Glac & 9590.0 & 26.6 & 0.00 & 7988.9 & 42.6 & 0.00 & 6196.3 & 88.4 & 0.00 \\
\hline & Ice + Repr & 9669.4 & 106.0 & 0.00 & 8079.8 & 133.5 & 0.00 & 6259.8 & 151.9 & 0.00 \\
\hline & Ice & 9683.9 & 120.4 & 0.00 & 8098.4 & 152.1 & 0.00 & 6307.5 & 199.6 & 0.00 \\
\hline & Glac & 15872.7 & 6309.2 & 0.00 & 13183.8 & 5237.5 & 0.00 & 10331.1 & 4223.2 & 0.00 \\
\hline & Repr & 21155.5 & 11592.1 & 0.00 & 17622.5 & 9676.2 & 0.00 & 13101.9 & 6994.0 & 0.00 \\
\hline \multirow[t]{3}{*}{ Fast ice } & Glac + Repr & 5422.5 & 3.1 & 0.15 & 4071.2 & 0.0 & 1.00 & 2639.6 & 0.0 & 1.00 \\
\hline & Repr & 5422.5 & 3.0 & 0.15 & 4094.7 & 23.4 & 0.00 & 2669.1 & 29.5 & 0.00 \\
\hline & Glac & 5419.5 & 0.0 & 0.70 & 4082.3 & 11.0 & 0.00 & 2673.0 & 33.4 & 0.00 \\
\hline \multirow[t]{3}{*}{ Pack ice } & Land + Repr & 3096.2 & 0.0 & 1.00 & 2899.2 & 0.0 & 0.99 & 2698.6 & 0.0 & 1.00 \\
\hline & Land & 3110.2 & 14.0 & 0.00 & 2908.7 & 9.5 & 0.01 & 2719.2 & 20.6 & 0.00 \\
\hline & Repr & 3119.8 & 23.6 & 0.00 & 2942.1 & 42.9 & 0.00 & 2749.3 & 50.7 & 0.00 \\
\hline
\end{tabular}




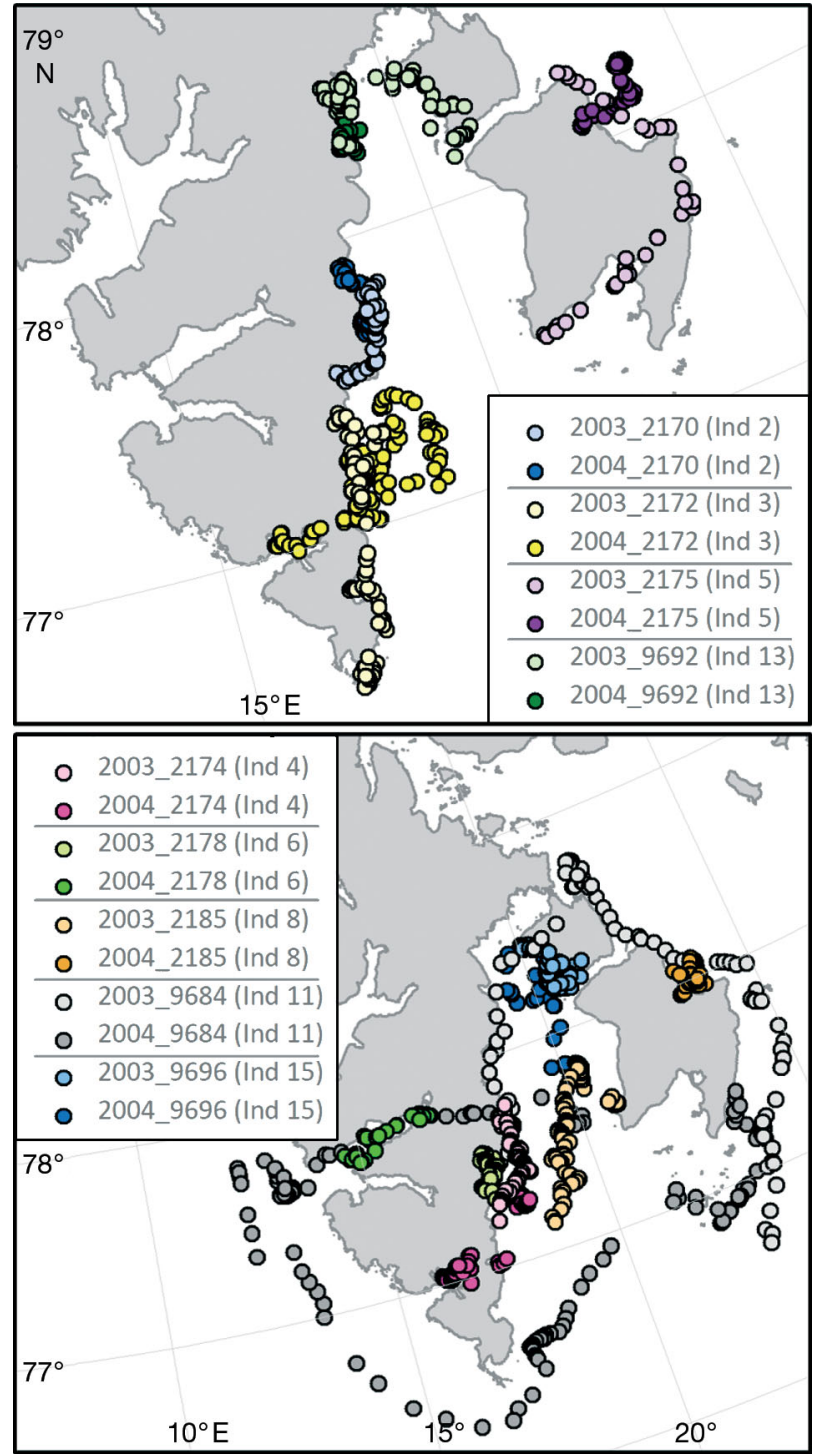

Fig. 3. Ursus maritimus. GPS locations obtained from 9 female polar bears tracked in 2 consecutive years. Locations are illustrated in 2 panels for increased readability. Keys show both track and individual identification

between individuals: $F_{2,13}=3.209, \mathrm{p}=0.074$ ). Distance to shore at the time of capture in April was not significantly different between females of different reproductive status (1-way ANOVA, $F_{2,8}=3.70, \mathrm{p}=0.073$ ).

SAR ice data showed that females with COYs used fast ice more frequently than pack-ice areas (Kruskal-Wallis, $H=15.60, \mathrm{df}=1, \mathrm{p}<0.001$; Table 2). Only 3 females with COYs were observed in pack ice, and these areas were located relatively close to shore (up to $16.8 \mathrm{~km}$ ). This is in contrast to lone adult females that used fast ice as frequently as pack-ice areas (Kruskal-Wallis, $H=0.16, \mathrm{df}=1, \mathrm{p}=0.690$;
Table 2). When in fast-ice areas, no differences were observed between females with COYs and lone adult females with regard to average distance to glacier fronts (mixed-effects ANOVA, differences between COYs and lone: $F_{1,2}=2.843, \mathrm{p}=0.234$; random variation between individuals: $F_{1,13}=1.619, \mathrm{p}=0.226$ ). No differences were observed between reproductive status with regard to distance to glacier fronts at the time of capture in April (1-way ANOVA, $F_{2,8}=4.10$, $\mathrm{p}=0.059$ ). Only 3 tracks were available from females with yearlings. These females were observed equally frequently in the 2 ice types (Kruskal-Wallis, $H=$ $0.05, \mathrm{df}=1, \mathrm{p}=0.822$ ). Only 1 bear was observed outside the main sea-ice edge, i.e. in pack-ice areas with $<50 \%$ sea-ice concentration, and this individual was a lone adult female (Table 2 ). Note that random variation between individuals could not be taken into account in the above Kruskal-Wallis tests. However, females with COYs used fast ice almost exclusively (see Table 2), and this clear pattern is unlikely to be a confounding effect between reproductive status and random variation between individuals.

Most polar bears exhibited ARS during the tracking period, concentrating their time in areas ranging from 2 to $18 \mathrm{~km}$ in radius (Table 2). No relationship was found between ARS radius and reproductive status (mixed-effects ANOVA, differences between reproductive status: $F_{2,2}=11.75, \mathrm{p}=0.078$; random variation between individuals: $F_{2,10}=5.17, \mathrm{p}=0.029$ ).

Cox proportional hazard modelling of FPTs showed that females with COYs were less mobile (had lower probabilities of leaving) than lone adult females, at the larger spatial scales (5 and $10 \mathrm{~km}$ ), as expected since the former group of bears displayed smaller home ranges. However, at the spatial scale of $2 \mathrm{~km}$, the 2 reproductive groups displayed similar probabilities of leaving (Fig. 4a), which indicates that at this scale they explored the environment in a similar way. The models also showed that females with yearlings were most mobile, even more so than lone females (Figs. 4a \& 5). While no apparent differences in FPTs were found between fast- and pack-ice habitats, a marked decrease in the probabilities of leaving was found at decreasing distances from glacier fronts (Fig. 4a). When female polar bears occupied fast-ice areas, the observed variation in the FPT data was better explained by distance to the nearest glacier front than by distance to shore (Table 3), and the probability of leaving increased significantly when moving more than 5 to $10 \mathrm{~km}$ from a glacier front (Fig. 4b). Females with COYs and lone adult females followed this behavioural pattern (Fig. 4d,e). We did not have enough data to explore the influence of 

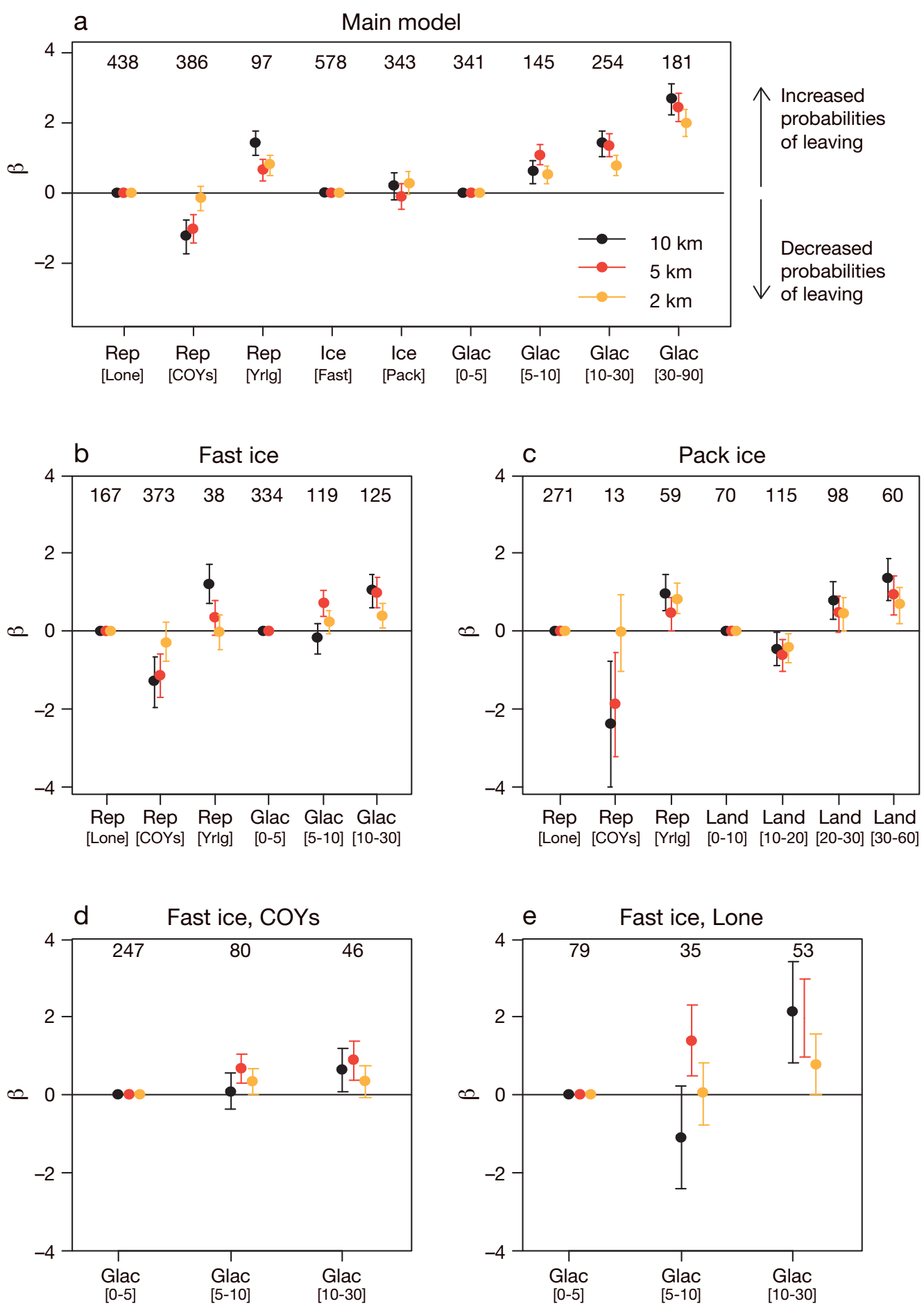

Fig. 4. Ursus maritimus. Estimated $\beta$ coefficients (and 95\% CI) from the mixed-effects Cox proportional hazard (CPH) models for the covariates affecting the risk of polar bears leaving a given area (of 2,5 or $10 \mathrm{~km}$ radius) in Svalbard during spring. Results from (a) the main model (all ice habitats and reproductive states), (b) fast-ice areas only and (c) pack-ice areas only. (d,e) Results of models for fast-ice areas, for females with cubs of the year (COYs) and lone adult females (Lone), respectively. Covariates included in the different models were: reproductive status (Rep), sea ice type (Ice), distance from glaciers (Glac) and distance from land (Land). The reproductive status 'lone female' was used as a base level, while 'fast ice', '0-5 km' and '0-10 km' radii were used as base levels for Ice, Glac and Land, respectively. A $\beta$-value $>0(<0)$ indicates an increased $($ decreased) probability of leaving; confidence intervals provide evidence for whether $\beta$ coefficients are significantly different from 0 . Number of observations is presented at the top of each panel. Yrlg: female with yearlings 


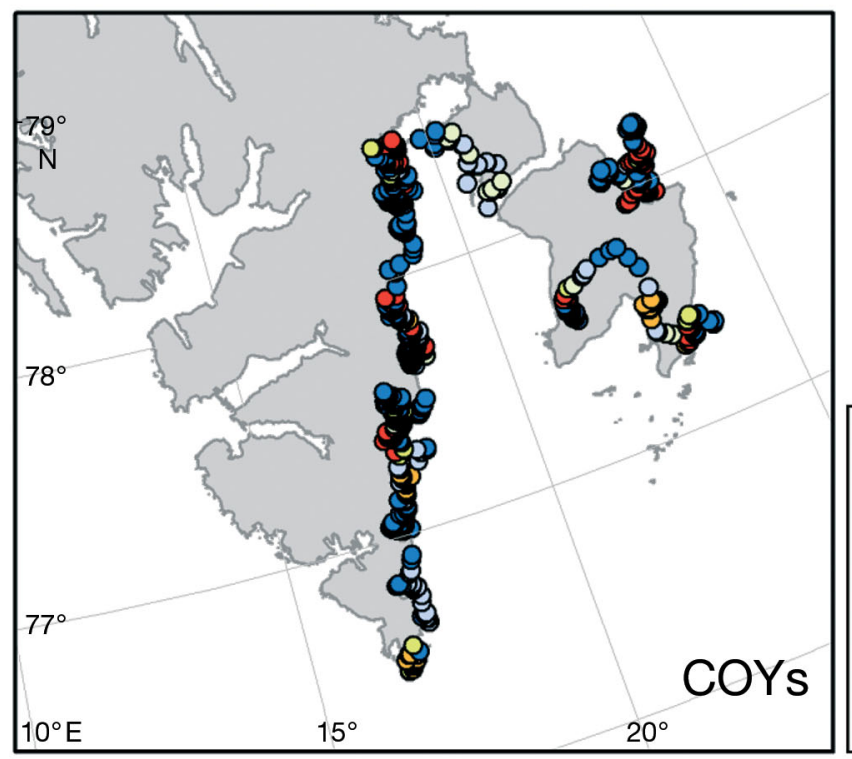

$$
\begin{aligned}
& \text { FPT (10 km) } \\
& 0 \quad 0-24 \mathrm{~h} \\
& 0>24-48 \mathrm{~h} \\
& 0>48-72 \mathrm{~h} \\
& 0>72-96 \mathrm{~h} \\
& 0>96-120 \mathrm{~h} \\
& 0>120 \mathrm{~h}(>5 \mathrm{~d})
\end{aligned}
$$

$0 \quad 50 \quad 100 \mathrm{~km}$
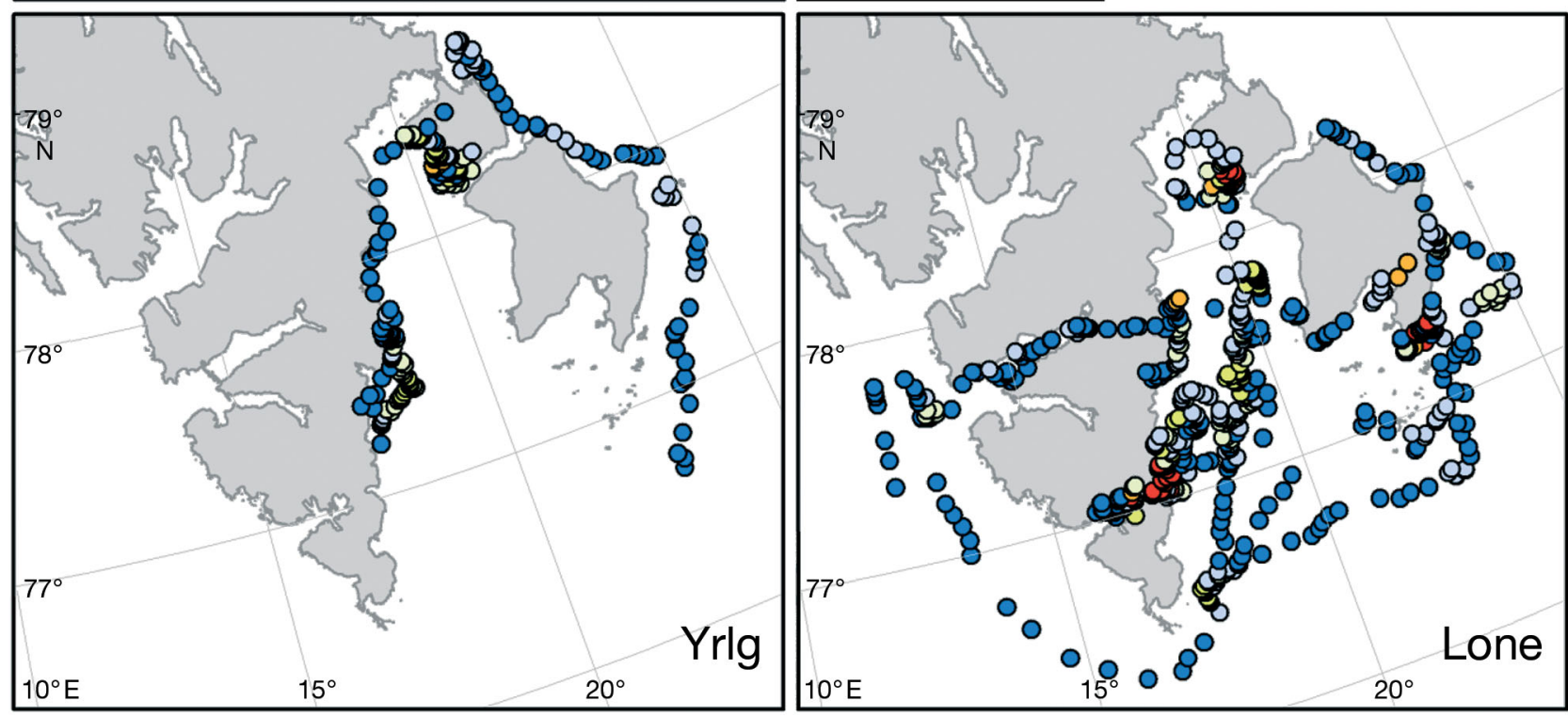

Fig. 5. Ursus maritimus. Polar bear GPS locations obtained in southern Svalbard in April 2003 and April 2004. Locations are colour coded according to first-passage time (FPT, $10 \mathrm{~km}$ radius) and are grouped by reproductive status (COYs: female with cubs of the year; Yrlg: female with yearlings; Lone: lone adult female)

glacier fronts on the movement patterns of females with yearlings (only 8 locations were available in fast-ice areas at $<5 \mathrm{~km}, 4$ at $5-10 \mathrm{~km}$ and 26 at $>10 \mathrm{~km}$ from glacier fronts). For polar bears in pack ice, probabilities of leaving increased significantly with increased (>20 km) distances to shore (Fig. 4c).

\section{DISCUSSION}

In this study, we found that female polar bears with COYs predominantly occupied inshore, fast-ice areas during spring (April), and within this habitat they spent a lot of their time near glacier fronts. A strong preference by female bears with young cubs for fast ice during spring has been previously reported from an aerial survey study in the Canadian Arctic (Stirling et al. 1993). However, in Svalbard, the bears concentrated their time in fast ice close to glacier fronts while in the Canadian Arctic they selected fast ice with snow drifts along pressure ridges, which were sometimes located far offshore. Both areas, in the respective locations, are linked to ringed seal breeding biology. Ringed seals give birth during spring 
inside lairs that are constructed in snow that accumulates in stable sea-ice areas (Smith \& Stirling 1975, Kingsley et al. 1985, Furgal et al. 1996). The presence of broken blocks of ice (either glacier ice blocks that calves off from glacier fronts typical of the fjords in Svalbard), or sea-ice pieces formed by pressure ridges (more typical in the Canadian Arctic) promote snow accumulation that permits ringed seal lair construction (Smith \& Stirling 1975, Kingsley et al. 1985, Lydersen \& Ryg 1991, Smith \& Lydersen 1991, Furgal et al. 1996, Krafft et al. 2007). Thus, although superficially it appears that females with COYs from Svalbard and Canada have different space-use strategies, this is not the case; glacier fronts are unavailable in the Canadian Arctic and pressure ridges are uncommon in Svalbard, but in the different regions these features accumulate snow and hence are good for ringed seal breeding. Female polar bears with COYs from both areas occupy fastice areas where ringed seal pupping occurs. It is of paramount importance for the nutritionally stressed females with COYs to have a predictable food source when emerging from the maternity dens in spring, and ringed seal pupping areas represent such a food source. The female bears can easily hunt ringed seal pups and sometimes their mothers (Stirling \& McEwan 1975, C. Lydersen pers. obs.), without having to move long distances. Accordingly, most females with COYs in the present study spent their entire tracking period in fast-ice habitats, close to known polar bear denning areas (Andersen et al. in press), displaying home ranges as small as $17 \mathrm{~km}^{2}$ ( $9 \mathrm{~d}$ period).

In addition to providing abundant food, these fastice areas represent a stable substrate for young polar bear cubs. Female polar bears with COYs seem to maintain this preference for stable ice areas, or at least areas with high ice densities, throughout the first year of life for the cubs (Mauritzen et al. 2003). Use of areas with low ice cover increases the risk of drifting away from the main ice fields (Mauritzen et al. 2003), which can only be returned to by swimming. Adult polar bears are extremely good swimmers (Durner et al. 2011) and are well insulated to cope with the cold ocean temperatures in the Arctic. However, spring COYs, in addition to being small (with a high surface to volume ratio promoting heat loss), also lack the insulating properties of the adult's thick blubber and fur. A 30 min immersion into ice water can reduce rectal temperature of a 3 mo old COY by $11^{\circ} \mathrm{C}$ (Blix \& Lentfer 1979), which clearly demonstrates that COYs are not able to swim over long distances. Anecdotal field observations also provided evidence for the limited swimming capacity of young polar bears; a female in the Beaufort Sea lost her yearling cub after a long-distance swim (Durner et al. 2011), and a female in Svalbard displayed behaviours that might serve to reduce heat loss in COYs when crossing open water (Aars \& Plumb 2010).

Small home ranges displayed by females with COYs compared to lone females are likely related in part to the avoidance of crossing unstable pack-ice areas. However, protection from predation by male polar bears has also been suggested as a possible reason for spatial segregation (Derocher \& Stirling 1990, Stirling et al. 1993, Ferguson et al. 1997). Stirling et al. (1993) found that adult males in Canada select ice-edge areas during spring and hypothesised that the selection of fast-ice areas by females with COYs could in part reflect avoidance of males. Infanticide and cannibalism of young polar bears (cubs and yearlings) by adult males has been observed repeatedly in Svalbard (Taylor et al. 1985, Derocher \& Wiig 1999, Stone \& Derocher 2007). While cannibalism is most likely to occur in summer or autumn when food availability is low (Ferguson et al. 1997), infanticide may be an issue during spring if adult males kill dependent offspring in order to obtain breeding opportunities with adult females, as has been previously speculated (see Hausfater \& Hrdy 1984). No data are available on habitat selection by adult males in Svalbard to explore this issue further.

Fidelity to the same geographic area, within Storfjorden, was observed for some bears tracked in consecutive years. Polar bears from the Svalbard/Barents Sea population show a high degree of seasonal fidelity (Mauritzen et al. 2001); site fidelity has also been observed in other polar bear populations (Stirling et al. 1977, 1980, 2004, Lentfer 1983, Bethke et al. 1996, Born et al. 1997, Taylor et al. 2001, Stirling 2002). Some females from the Svalbard/Barents Sea population stay near shore on a year-round basis, while others move offshore and have much larger home ranges; the same individuals display the same spatial patterns year after year (Mauritzen et al. 2001). It is not known whether females in this study belonged to the 'near-shore' or the 'offshore' group, since movements outside the study period were not analysed. However, they all displayed smaller home ranges when they had COYs compared to when they were alone.

Lone adult females and females with yearlings in the present study were often located in fast-ice areas. However, unlike females with COYs, they also explored offshore pack-ice areas, and their FPTs were significantly shorter in the offshore pack ice, indicating that they moved faster and in a more 
directed manner in this habitat. The use of drift ice by lone females may be due to their greater mobility, compared to females with COYs, which allows them to use other profitable hunting areas beyond those near glacier fronts.

Ringed seal density in April is low in pack-ice areas compared to their fast-ice breeding habitats, but non-breeding ringed seals can be found at the periphery of fast-ice areas and in the drifting ice outside it during this time of the year (Krafft et al. 2007). In addition, bearded seals Erignathus barbatus and harp seals Pagophilus groenlandicus occur in the pack-ice areas around Svalbard during spring (Haug et al. 1994, Isaksen \& Wiig 1995), and these species have been recorded in the diet of polar bears from this area (Lønø 1970, Derocher et al. 2002). Even if the seal density is lower in the pack ice, bearded and harp seals are larger prey than ringed seals. It is therefore possible that female polar bears in Svalbard face a trade-off between being in fast-ice areas that provide a safe substrate (especially for cubs) and where prey items are predictable but small, and being in less stable drift ice where prey items are more unpredictable but also more profitable.

Although lone adult females had larger home ranges than females with COYs on average, a high degree of variability between individuals was observed. The small home ranges displayed by some lone females might have been connected to mating behaviour. Field studies of polar bears show that male bears often herd females into isolated areas during the mating season, e.g. on top of islands, small bays or tops of cliffs (Ramsay \& Stirling 1986, Wiig et al. 1992, Derocher et al. 2010), and that a pair can stay together for periods up to $16 \mathrm{~d}$ (Derocher et al. 2010). Two of the smallest home ranges among lone adult females in this study were displayed by females that were escorted by an adult male at the time of capture (see Table 2).

Female polar bears with yearlings are less limited by mobility/swimming issues compared to females with COYs, and they are not involved in mating. They are therefore the reproductive group with the most freedom to move around during the season of the year that this study encompassed. This is reflected by the short FPTs displayed in this group. Only 1 bear (a lone female) in this study was observed outside the main sea-ice edge, i.e. in packice areas with $<50 \%$ sea ice concentration. This observation is in accordance with previous studies that also report a preference for sea-ice areas with concentrations above 50 to $60 \%$ (Arthur et al. 1996, Ferguson et al. 2000a, Durner et al. 2009).
We used high-accuracy location data (GPS data) and high-resolution sea-ice data in this study to explore space use by female polar bears in Svalbard during spring. The results obtained with regard to the use of near-shore fast ice would have been very difficult to extract using less accurate location data (such as Argos locations) given the small size of the fast-ice areas, especially those located along the west coast of Storfjorden. Less accurate locations could result in bears being classified as being on shore or on pack ice while in actuality they were situated on fast ice close to glacier fronts. The freely available gridded sea-ice data for Svalbard, often used in these types of analyses, have resolutions larger than $5 \mathrm{~km}$ (often 10 or $25 \mathrm{~km}$ ) and generally do not present data for pixels that include land at all (in order to prevent inaccurate ice classifications in the pixels 'contaminated' by land; Eastwood 2011). However, using accurate GPS location data and high-resolution SAR sea-ice data, a strong preference for fast ice, and particularly fast ice close to glacier fronts, was demonstrated for female polar bears with COYs.

Arctic sea ice is declining rapidly (Comiso 2002, Lindsay \& Zhang 2005, Stroeve et al. 2005, 2007 , Maslanik et al. 2007, Nghiem et al. 2007, Comiso et al. 2008, Kwok et al. 2009), and this is a concern for the conservation of polar bears, given the critical importance of this habitat for this species (Stirling \& Derocher 1993, Derocher et al. 2004, Aars et al. 2006, Stirling \& Parkinson 2006, Wiig et al. 2008, Amstrup et al. 2010). Our results in this study clearly emphasise the importance of coastal fast ice, in particular fast ice close to glacier fronts, for polar bear females with young cubs in Svalbard. Although such habitats are not available in many areas of the polar bear range, they are likely to be important for bears in all regions with similar habitat characteristics (e.g. Greenland). In Svalbard, large reductions in fast-ice surfaces have been observed in recent years (Høyland 2009, Zajaczkowski et al. 2010). Additionally, glacier fronts that have contact with the ocean have also been retreating in Svalbard (Blaszczyk et al. 2009). Field observations in Kongsfjorden and other west-coast fjords in Svalbard indicate virtually no ringed seal production in recent years when fast ice formed late or not at all (K. M. Kovacs \& C. Lydersen pers. obs.). The eventual disappearance of these prey-rich, stable habitats where polar bear females with COYs concentrate their hunting efforts during spring (fast-ice areas, in particular close to glacier fronts) might become critical for the survival of polar bear cubs in Svalbard as well as in other Arctic areas. 
Acknowledgements. This study was funded by the Norwegian Research Council (seals, bears and ice project) and the Norwegian Polar Institute. We thank R. A. Ims for valuable statistical advice.

\section{LITERATURE CITED}

Aars J, Plumb A (2010) Polar bear cubs may reduce chilling from icy water by sitting on mother's back. Polar Biol 33: $557-559$

Aars J, Lunn NJ, Derocher AE (2006) Polar bears-Proc 14th Working Meeting of the IUCN/SSC Polar Bear Specialists Group, 20-24 June 2005, Seattle, WA. Occasional Paper 32. International Union for Conservation of Nature and Natural Resources Species Survival Commission, Gland

Amstrup SC, Gardner C (1994) Polar bear maternity denning in the Beaufort Sea. J Wildl Manag 58:1-10

> Amstrup SC, Durner GM, Stirling I, Lunn NN, Messier F (2000) Movements and distribution of polar bears in the Beaufort Sea. Can J Zool 78:948-966

> Amstrup SC, DeWeaver ET, Douglas DC, Marcot BG, Durner GM, Bitz CM, Bailey DA (2010) Greenhouse gas mitigation can reduce sea-ice loss and increase polar bear persistence. Nature 468:955-958

$>$ Andersen M, Derocher AE, Wiig Ø, Aars J (2008) Movements of two Svalbard polar bears recorded using geographical positioning system satellite transmitters. Polar Biol 31:905-911

Andersen M, Derocher AE, Wiig Ø, Aars J (2011) Polar bear (Ursus maritimus) maternity den distribution in Svalbard, Norway. Polar Biol (in press) doi:10.1007/s00300-0111094-y

Arthur SM, Manly BFJ, McDonald LL, Garner GW (1996) Assessing habitat selection when availability changes. Ecology 77:215-227

> Atkinson SN, Ramsay MA (1995) The effects of prolonged fasting on the body-composition and reproductive success of female polar bears (Ursus maritimus). Funct Ecol 9:559-567

Bethke R, Taylor M, Amstrup S, Messier F (1996) Population delineation of polar bears using satellite collar data. Ecol Appl 6:311-317

Blaszczyk M, Jania JA, Hagen JO (2009) Tidewater glaciers of Svalbard: recent changes and estimates of calving fluxes. Pol Polar Res 30:85-142

> Blix AS, Lentfer JW (1979) Modes of thermal protection in polar bear cubs - at birth and on emergence from the den. Am J Physiol 236:R67-R74

> Boe JL, Hall A, Qu X (2009) September sea-ice cover in the Arctic Ocean projected to vanish by 2100 . Nat Geosci 2: 341-343

Born EW, Wiig Ø, Thomassen J (1997) Seasonal and annual movements of radio-collared polar bears (Ursus maritimus) in northeast Greenland. J Mar Syst 10: $67-77$

Burnham KP, Anderson DR (2002) Model selection and multimodel inference: a practical information-theoretic approach. Springer-Verlag, New York, NY

$>$ Calenge C (2006) The package 'adehabitat' for the R software: a tool for the analysis of space and habitat use by animals. Ecol Model 197:516-519

Comiso JC (2002) A rapidly declining perennial sea ice cover in the Arctic. Geophys Res Lett 29:1956
Comiso JC, Parkinson CL, Gersten R, Stock L (2008) Accelerated decline in the Arctic sea ice cover. Geophys Res Lett 35:L01703

Derocher AE, Stirling I (1990) Distribution of polar bears (Ursus maritimus) during the ice-free period in western Hudson Bay. Can J Zool 68:1395-1403

Derocher AE, Wiig $\varnothing$ (1999) Infanticide and cannibalism of juvenile polar bears (Ursus maritimus) in Svalbard. Arctic 52:307-310

Derocher AE, Wiig $\varnothing$, Andersen M (2002) Diet composition of polar bears in Svalbard and the western Barents Sea. Polar Biol 25:448-452

> Derocher AE, Lunn NJ, Stirling I (2004) Polar bears in a warming climate. Integr Comp Biol 44:163-176

> Derocher AE, Andersen M, Wiig Ø, Aars J (2010) Sexual dimorphism and the mating ecology of polar bears (Ursus maritimus) at Svalbard. Behav Ecol Sociobiol 64:939-946

> Durner GM, Douglas DC, Nielson RM, Amstrup SC and others (2009) Predicting 21st-century polar bear habitat distribution from global climate models. Ecol Monogr 79: $25-58$

> Durner GM, Whiteman JP, Harlow HJ, Amstrup SC, Regehr EV, Ben-David M (2011) Consequences of long-distance swimming and travel over deep-water pack ice for a female polar bear during a year of extreme sea ice retreat. Polar Biol 34:975-984

Eastwood S (2011) Sea ice product manual, version 3.7. Ocean \& Sea Ice SAF. Available at http://saf.met.no/ docs/osisaf_ss2_pum_ice-conc-edge-type_v3p7.pdf

Fauchald P, Tveraa T (2003) Using first-passage time in the analysis of area-restricted search and habitat selection. Ecology 84:282-288

Fauchald P, Tveraa T (2006) Hierarchical patch dynamics and animal movement pattern. Oecologia 149:383-395

Ferguson SH, Taylor MK, Messier F (1997) Space use by polar bears in and around Auyuittuq National Park, Northwest Territories, during the ice-free period. Can J Zool 75:1585-1594

> Ferguson SH, Taylor MK, Born EW, Rosing-Asvid A, Messier F (1999) Determinants of home range size for polar bears (Ursus maritimus). Ecol Lett 2:311-318

Ferguson SH, Taylor MK, Messier F (2000a) Influence of sea ice dynamics on habitat selection by polar bears. Ecology 81:761-772

Ferguson SH, Taylor MK, Rosing-Asvid A, Born EW, Messier F (2000b) Relationships between denning of polar bears and conditions of sea ice. J Mammal 81: 1118-1127

Ferguson SH, Taylor MK, Born EW, Rosing-Asvid A, Messier F (2001) Activity and movement patterns of polar bears inhabiting consolidated versus active pack ice. Arctic 54:49-54

Freitas C, Kovacs KM, Lydersen C, Ims RA (2008) A novel method for quantifying habitat selection and predicting habitat use. J Appl Ecol 45:1213-1220

> Furgal CM, Innes S, Kovacs KM (1996) Characteristics of ringed seal, Phoca hispida, subnivean structures and breeding habitat and their effects on predation. Can J Zool 74:858-874

Haarpaintner J, Haugan PM, Gascard JC (2001) Interannual variability of the Storfjorden (Svalbard) ice cover and ice production observed by ERS-2 SAR. In: Jeffries MO, Eicken H (eds) Annals of glaciology, Vol 33. International Glaciological Society, Cambridge, p 430-436 
Haug T, Nilssen KT, Oien N, Potelov V (1994) Seasonal distribution of harp seals (Phoca groenlandica) in the Barents Sea. Polar Res 13:163-172

Hausfater G, Hrdy SB (1984) Infanticide: comparative and evolutionary perspectives. Aldine Publishing Company, New York, NY

> Holland MM, Bitz CM, Tremblay B (2006) Future abrupt reductions in the summer Arctic sea ice. Geophys Res Lett 33:L23503 doi:10.1029/2006GL028024

> Høyland KV (2009) Ice thickness, growth and salinity in Van Mijenfjorden, Svalbard, Norway. Polar Res 28:339-352

> Hunter CM, Caswell H, Runge MC, Regehr EV, Amstrup SC, Stirling I (2010) Climate change threatens polar bear populations: a stochastic demographic analysis. Ecology 91:2883-2897

IPCC (Intergovernmental Panel on Climate Change) (2007) IPCC WGI Assessment Report. IPCC Secretariat, Geneva

Isaksen K, Wiig Ø (1995) Seasonal distribution of harbour seals, bearded seals, white whales and polar bears in the Barents Sea. Nor Polarinst Meddel 136:47-59

Kingsley MCS, Stirling I, Calvert W (1985) The distribution and abundance of seals in the Canadian High Arctic, 1980-82. Can J Fish Aquat Sci 42:1189-1210

Krafft BA, Kovacs KM, Lydersen C (2007) Distribution of sex and age groups of ringed seals Pusa hispida in the fastice breeding habitat of Kongsfjorden, Svalbard. Mar Ecol Prog Ser 335:199-206

Kwok R, Cunningham GF, Wensnahan M, Rigor I, Zwally HJ, Yi D (2009) Thinning and volume loss of the Arctic Ocean sea ice cover: 2003-2008. J Geophys Res 114: C07005 doi:10.1029/2009JC005312

Lentfer JW (1983) Alaskan polar bear movements from mark and recovery. Arctic 36:282-288

Lindsay RW, Zhang J (2005) The thinning of arctic sea ice, 1988-2003: Have we passed a tipping point? J Clim 18: 4879-4894

Lønø O (1970) The polar bear (Ursus maritimus Phipps) in the Svalbard area. Norsk Polarinst Skr 149:1-15

Lydersen C (1998) Status and biology of ringed seals (Phoca hispida) in Svalbard. NAMMCO Sci Pub 1:46-62

Lydersen C, Ryg M (1991) Evaluating breeding habitat and populations of ringed seals Phoca hispida in Svalbard fjords. Polar Rec 27:222-228

Maslanik JA, Fowler C, Stroeve J, Drobot S, Zwally J, Yi D, Emery W (2007) A younger, thinner Arctic ice cover: increased potential for rapid, extensive sea-ice loss. Geophys Res Lett 34:L24501 doi:10.1029/2007GL032043

- Mauritzen M, Derocher AE, Wiig Ø (2001) Space-use strategies of female polar bears in a dynamic sea ice habitat. Can J Zool 79:1704-1713

Mauritzen M, Belikov SE, Boltunov AN, Derocher A and others (2003) Functional responses in polar bear habitat selection. Oikos 100:112-124

Messier F, Taylor MK, Ramsay MA (1992) Seasonal activity patterns of female polar bears (Ursus maritimus) in the Canadian Arctic as revealed by satellite telemetry. J Zool (Lond) 226:219-229

Messier F, Taylor MK, Ramsay MA (1994) Denning ecology of polar bears in the Canadian Arctic archipelago. J Mammal 75:420-430

Mohr CO (1947) Table of equivalent populations of North American small mammals. Am Midl Nat 37:223-249

Molnar PK, Derocher AE, Thiemann GW, Lewis MA (2010) Predicting survival, reproduction and abundance of polar bears under climate change. Biol Conserv 143: 1612-1622

Nghiem SV, Rigor IG, Perovich DK, Clemente-Colon P, Weatherly JW, Neumann G (2007) Rapid reduction of Arctic perennial sea ice. Geophys Res Lett 34:L19504 doi:10.1029/2007GL031138

R Development Core Team (2010) R: a language and environment for statistical computing. R Foundation for Statistical Computing, Vienna. www.r-project.org

Ramsay MA, Stirling I (1986) On the mating system of polar bears. Can J Zool 64:2142-2151

> Ramsay MA, Stirling I (1988) Reproductive biology and ecology of female polar bears (Ursus maritimus). J Zool 214:601-634

> Regehr EV, Lunn NJ, Amstrup SC, Stirling L (2007) Effects of earlier sea ice breakup on survival and population size of polar bears in western Hudson Bay. J Wildl Manag 71: 2673-2683

Regehr EV, Hunter CM, Caswell H, Amstrup SC, Stirling I (2010) Survival and breeding of polar bears in the southern Beaufort Sea in relation to sea ice. J Anim Ecol 79: $117-127$

> Rode KD, Amstrup SC, Regehr EV (2010) Reduced body size and cub recruitment in polar bears associated with sea ice decline. Ecol Appl 20:768-782

Rosing-Asvid A, Born EW, Kingsley MCS (2002) Age at sexual maturity of males and timing of the mating season of polar bears (Ursus maritimus) in Greenland. Polar Biol 25:878-883

Serreze MC, Holland MM, Stroeve J (2007) Perspectives on the Arctic's shrinking sea-ice cover. Science 315: 1533-1536

Skogseth R, Haugan PM, Haarpaintner J (2004) Ice and brine production in Storfjorden from four winters of satellite and in situ observations and modeling. J Geophys Res 109:C10008 doi:10.1029/2007JC002384

Smedrud LH, Budgell WP, Jenskins AD, Ådlandsvik B (2006) Fine-scale sea-ice modelling of the Storfjorden polynya, Svalbard. Ann Glaciol 44:1-7

Smith TG (1980) Polar bear predation of ringed and bearded seals in the land-fast sea ice habitat. Can J Zool 58: 2201-2209

Smith TG, Lydersen C (1991) Availability of suitable land-fast ice and predation as factors limiting ringed seal populations, Phoca hispida, in Svalbard. Polar Res 10:585-594

Smith TG, Stirling I (1975) The breeding habitat of the ringed seal (Phoca hispida). The birth lair and associated structures. Can J Zool 53:1297-1305

Stirling I (1997) The importance of polynyas, ice edges, and leads to marine mammals and birds. J Mar Syst 10:9-21

Stirling I (2002) Polar bears and seals in the eastern Beaufort Sea and Amundsen Gulf: a synthesis of population trends and ecological relationships over three decades. Arctic 55:59-76

Stirling I, Archibald WR (1977) Aspects of predation of seals by polar bears. J Fish Res Board Can 34:1126-1129

Stirling I, Derocher AE (1993) Possible impacts of climatic warming on polar bears. Arctic 46:240-245

Stirling I, McEwan EH (1975) Caloric value of whole ringed seals (Phoca hispida) in relation to polar bear (Ursus maritimus) ecology and hunting behavior. Can J Zool 53: 1021-1027

Stirling I, Parkinson CL (2006) Possible effects of climate warming on selected populations of polar bears (Ursus maritimus) in the Canadian Arctic. Arctic 59:261-275 
Stirling I, Jonkel C, Smith P, Robertson R (1977) The ecology of the polar bear (Ursus maritimus) along the western coast of Hudson Bay. Occas Pap Can Wildl Serv 33:1-64

Stirling I, Calvert W, Andriashek D (1980) Population ecology studies of the polar bear in the area of southeastern Baffin Island. Occas Pap Can Wildl Serv 44: 1-30

Stirling I, Spencer C, Andriashek D (1989) Immobilization of polar bears (Ursus maritimus) with Telazol in the Canadian Arctic. J Wildl Dis 25:159-168

Stirling I, Andriashek D, Calvert W (1993) Habitat preferences of polar bears in the western Canadian Arctic in late winter and spring. Polar Rec 29:13-24

Stirling I, Lunn NJ, Iacozza J (1999) Long-term trends in the population ecology of polar bears in western Hudson Bay in relation to climatic change. Arctic 52:294-306

Stirling I, Lunn NJ, Iacozza J, Elliott C, Obbard M (2004) Polar bear distribution and abundance on the southwestern Hudson Bay coast during open water season, in relation to population trends and annual ice patterns. Arctic 57:15-26

Stone IR, Derocher AE (2007) An incident of polar bear infanticide and cannibalism on Phippsoya, Svalbard. Polar Rec 43:171-173

Stroeve JC, Serreze MC, Fetterer F, Arbetter T, Meier W, Maslanik J, Knowles K (2005) Tracking the Arctic's shrinking ice cover: another extreme September minimum in 2004. Geophys Res Lett 32:L04501 doi:10.1029/ 2004GL021810

Stroeve J, Holland MM, Meier W, Scambos T, Serreze M (2007) Arctic sea ice decline: faster than forecast. Geophys Res Lett 34:L09501 doi:10.1029/2007GL029703

Editorial responsibility: Rory Wilson,

Swansea, UK
Taylor M, Larsen T, Schweinsburg RE (1985) Observations of intraspecific aggression and cannibalism in polar bears (Ursus maritimus). Arctic 38:303-309

Taylor MK, Akeeagok S, Andriashek D, Barbour W and others (2001) Delineating Canadian and Greenland polar bear (Ursus maritimus) populations by cluster analysis of movements. Can J Zool 79:690-709

> Thiemann GW, Iverson SJ, Stirling I (2008) Polar bear diets and Arctic marine food webs: insights from fatty acid analysis. Ecol Monogr 78:591-613

Van de Velde F, Stirling I, Richardson E (2003) Polar bear (Ursus maritimus) denning in the area of the Simpson Peninsula, Nunavut. Arctic 56:191-197

Vinnikov KY, Robock A, Stouffer RJ, Walsh JE and others (1999) Global warming and northern hemisphere sea ice extent. Science 286:1934-1937

Watts PD, Hansen SE (1987) Cyclic starvation as a reproductive strategy in the polar bear. Symp Zool Soc Lond 57: 305-318

Wiig $\varnothing$ (1998) Survival and reproductive rates for polar bears at Svalbard. Ursus 10:25-32

> Wiig Ø, Gjertz I, Hansson R, Thomassen J (1992) Breeding behaviour of polar bears in Hornsund, Svalbard. Polar Rec 28:157-159

> Wiig Ø, Aars J, Born EW (2008) Effects of climate change on polar bears. Sci Prog 91:151-173

> Zajaczkowski M, Nygard H, Hegseth EN, Berge J (2010) Vertical flux of particulate matter in an Arctic fjord: the case of lack of the sea-ice cover in Adventfjorden 2006-2007. Polar Biol 33:223-239

Submitted: June 17, 2011; Accepted: November 21, 2011

Proofs received from author(s): January 29, 2012 